\title{
COLLAGENASE PRODUCTION BY YEAST (13II) ISOLATED FROM BEE POLLEN (Melípona spp.)
}

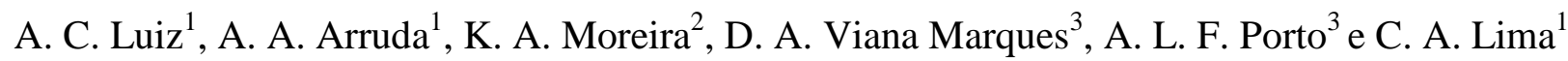 \\ ${ }^{1}$ Universidade de Pernambuco, Campus Garanhuns \\ ${ }^{2}$ Universidade Federal Rural de Pernambuco, Campus Garanhuns \\ ${ }^{3}$ Universidade Federal Rural de Pernambuco, Departamento de Morfologia e Fisiologia Animal \\ carolaalbuquerque18@hotmail.com
}

\begin{abstract}
Collagenases are enzymes with various important industrial and biotechnological applications. To be economically feasible, collagenase production should have high yields and use an inexpensive medium. The aim of this work was to study the influence of substrate concentration, $\mathrm{pH}$ and orbital agitation speed on collagenase production by yeast (13II) isolated from bee pollen (Melípona spp.) using a $2^{3}$ full factorial design. The experiments were performed in $250 \mathrm{~mL}$ Erlenmeyer flasks containing $50 \mathrm{~mL}$ of culture medium inoculated with $10^{6}$ cells $/ \mathrm{mL}$ and incubated for $72 \mathrm{~h}$ at $28{ }^{\circ} \mathrm{C}$. Substrate concentration and initial medium $\mathrm{pH}$ exerted significant positive main effects, while the orbital agitation speed exerted a negative effect on collagenase production. The most favorable production conditions were found to be with $1.25 \%$ of gelatin, $\mathrm{pH} 7.5$ and 100 rpm, which led to a collagenase activity of $66.86 \mathrm{U}$. These results show that the yeast was found to be able to produce a large amount of colagenase.
\end{abstract}

\section{INTRODUCTION}

Collagenases are proteolytic enzymes responsible for the degradation of the helical region of native collagen into small fragments. In contrast to mammalian collagenases, which cleave the collagen helix at a single site, microbial collagenases attack multiple sites along the helix (Hamdy, 2008).

In the past, much attention has been given to the isolation of collagenases from animal tissues. Recently, the emphasis has shifted to obtaining collagenases from microbes, which are an advantageous source in comparison with animals (Wu et al., 2010). Among the advantages, the availability of low-cost substrates, the extensive natural sources of microorganisms, and the simple procedures for isolation and purification of the final product may be cited (Suhosyrova et al., 2003).

In this decade, collagenase research has gained momentum because of additional therapeutic, industrial, and biotechnological applications other than those of conventional proteases (Benito et al., 2002; Kim et al., 2007; Kanth et al., 2008). Potential therapeutic applications include treatment of Peyronie's disease (Jordan, 2008), various types of destructive fibrosis such as arterial chronic occlusions (Segev et al., 2005) and postoperative abdominal adhesion (Tander et al., 2007). Collagenases also find application in the leather industry, where they are used as biocatalysts to improve dye exhaustion (Kanth et al., 2008) 
and in the food industry, for ripening and generating the flavor of dry-cured meat products (Benito et al., 2002). In the pharmaceutical sector, various commercially available collagenase formulations are used for wound treatment (Tamai et al., 2008). Collagenase also hydrolyses bovine trachea cartilage, allowing the cultivation of intact mammalian cells and cleaning blood cells for improved screening in medical diagnostics (Kim et al., 2007).

Given the potential uses of collagenases and their high demand, there is an interest in finding new micobial strains able to produce collagenases with novel properties, and in developing low-cost industrial media formulations. Media composition is one of the most important parameters in the industrial production of enzymes, because $30-40 \%$ of the production costs are due to the growth media. In fermentation technology, productivity improvements of the microbial proteases are achieved, in general, via the manipulation of nutritional and physical parameters, such as carbon and nitrogen sources, $\mathrm{pH}$, temperature, inoculum density, dissolved oxygen, and incubation time (Reddy et al., 2008; Haddar et al., 2010)

The cost of enzyme production is a major obstacle in successful industrial applications. To be economically feasible, industrial collagenase production should have high yields and use an inexpensive medium. In this work, we report on the use of factorial design to determine the most favorable conditions for collagenase production by the yeast isoleted from bee pollen (Melípona spp.).

\section{MATERIALS AND METHODS}

\subsection{Microorganism and culture conditions}

The yeast used in this study was isolate from bee pollen (Melipona spp.). The yeast (13II) was maintained at $4{ }^{\circ} \mathrm{C}$ on Sabouraud dextrose agar slants. The culture medium described by Nickerson and Mohan (1953), composed of gelatin at different concentrations, $0.025 \mathrm{~g} / \mathrm{L} \mathrm{MgSO} 4.7 \mathrm{H}_{2} \mathrm{O}, 1.5 \mathrm{~g} / \mathrm{L} \mathrm{K}_{2} \mathrm{HPO}_{4}, 0.015 \mathrm{~g} / \mathrm{L} \mathrm{FeSO}{ }_{4} .7 \mathrm{H}_{2} \mathrm{O}, 0.025 \mathrm{CaCl}_{2}, 0.005 \mathrm{~g} / \mathrm{L}$ $\mathrm{ZnSO}_{4} .7 \mathrm{H}_{2} \mathrm{O}$, was used for collagenase production. This fermentation medium was sterilized in an autoclave at $121^{\circ} \mathrm{C}$ for $20 \mathrm{~min}$.

\subsection{Screening of significant variables for collagenase production}

The $2^{3}$ full design mentioned above was carried out at all combinations of the levels given in Table 1. The central point was run in quadruplicate, to provide an estimate of the pure error variance in the experimental responses. From that, experimental errors of the effects were estimated and used to assess the significance of the effects and interactions of the independent variables - initial medium $\mathrm{pH}$, substrate concentration and orbital agitation speed - on the collagenase production.

The full $2^{3}$ model comprises a constant term, three main effects, three two-factor interaction effects and a three-factor interactions. The goodness-of-fit of this model was evaluated by analysis of variance. The statistical significance of each effect, at $95 \%$ confidence level, was assessed by comparisons with the experimental pure error obtained from the replicate runs at the central point. All statistical and graphical analyses were carried out by the Statistica 8.0 software (StatSoft Inc., Tulsa, OK, USA). 
Table 1 - Factor levels used in the $2^{3}$ design to investigate the production of collagenase by yeast (13II).

\begin{tabular}{lccc}
\hline & \multicolumn{3}{c}{ Level } \\
\cline { 2 - 4 } Factors & Lowest $(\mathbf{- 1})$ & Central $(\mathbf{0})$ & Highest $(+\mathbf{1})$ \\
\hline Substrate concentration $(\%, \mathrm{w} / \mathrm{v})$ & 0.75 & 1.00 & 1.25 \\
Initial medium $\mathrm{pH}$ & 5.5 & 6.5 & 7.5 \\
Orbital agitation speed $(\mathrm{rpm})$ & 100 & 150 & 200 \\
\hline
\end{tabular}

\subsection{Collagenase production}

Collagenase was obtained from a culture supernatant as follows. The strain was sub-cultured on $125 \mathrm{~mL}$ Erlenmeyer flask containing $25 \mathrm{~mL}$ of Sabouraud medium, $\mathrm{pH}$ 6.5, incubated at $28{ }^{\circ} \mathrm{C}$ and $140 \mathrm{rpm}$, for $24 \mathrm{~h}$. A calibrated cellular suspension $(A 600=0.1$, corresponding to an average cell concentration of $10^{6}$ cells $/ \mathrm{ml}$ ) was used to inoculate a $250 \mathrm{ml}$ Erlenmeyer flask containing 50 $\mathrm{ml}$ of culture medium and grown for $72 \mathrm{~h}$ at $28^{\circ} \mathrm{C}$ in an orbital incubator shaker at diferrent orbital agitation speed .The broth obtained at the end of fermentation $(72 \mathrm{~h})$ was centrifuged at $15,000 \times \mathrm{g}$ and $4{ }^{\circ} \mathrm{C}$ for $20 \mathrm{~min}$ to remove the cells. Since the target collagenase was an extracellular one, the supernatant was analyzed to determine the collagenase activity.

\subsection{Biomass determination}

Biomass was determined by the dry weight method using pre-weighted nitrocellulose membranes with $0.45 \mu \mathrm{m}$-pore diameter, after drying at $80^{\circ} \mathrm{C}$ for $24 \mathrm{~h}$.

\subsection{Azocoll assay for collagenase activity determination}

The Azo dye impregnated collagen-Azocoll (Sigma Chemical Co., St Louis, MO) assay was carried out according to a modified version of the method developed by Chavira et al. (1984). Azocoll was washed and suspended in $0.05 \mathrm{M}$ Tris-HCl buffer ( $\mathrm{pH} 7.2$ ) containing 1 $\mathrm{mM} \mathrm{CaCl} 2$ up to a final concentration of $0.5 \%(\mathrm{w} / \mathrm{v})$. After this, $150 \mu \mathrm{L}$ of cell-free filtrate and $150 \mu \mathrm{L}$ of buffer were mixed with $270 \mu \mathrm{L}$ of azocoll suspension in a 2.0 mL-reaction tube. The reaction tubes were incubated at $37^{\circ} \mathrm{C}$ in a water bath under agitation. After $3 \mathrm{~h}$ of incubation, the samples were chilled in ice for $5 \mathrm{~min}$ to stop the reaction and centrifuged at $10,000 \times \mathrm{g}$ and $4{ }^{\circ} \mathrm{C}$ for $20 \mathrm{~min}$ (model KR-20000T, Kubota Seisakusho, Tokyo, Japan). The absorbance of the supernatant was measured at $520 \mathrm{~nm}$ by means of a UV-Vis spectrophotometer, model B582 (Micronal, São Paulo, Brazil). One unit of enzyme activity (U) was defined as the amount of enzyme, per $\mathrm{mL}$ of crude extract that led, after $3 \mathrm{~h}$ of incubation, to an absorbance increase of 0.1 at $520 \mathrm{~nm}$, as a result of the formation of azo dyelinked soluble peptides.

\subsection{Protein determination}


Protein concentration was determined according to Smith et al. (1985), using bovine serum albumin as standard.

\section{RESULTS AND DISCUSSION}

The statistical analysis was performed for all the responses biomass and collagenolytic activity however, the last one was the response that was really important and was used for the analysis of the efficiency of enzyme production by microorganism.

The conditions and results obtained with the $2^{3}$ full factorial design are shown in Table 2. Analyzing the results, it was verified that the experiment with the number 4 showed the higher value $(66.86 \mathrm{U} / \mathrm{ml})$ of collagenolytic activity and biomass $(1.86 \mathrm{~g} / \mathrm{L})$. This condition corresponded to a $1.25 \%$ substrate concentration, orbital agitation of $100 \mathrm{rpm}$ and $\mathrm{pH} 7.5$.

Table 2 - Conditions and results of yeast (13II) fermentations performed according to the $2^{3}$ full factorial design ${ }^{\mathrm{a}}$.

\begin{tabular}{cccccc}
\hline Run & $\mathbf{p H}$ & $\mathbf{S}_{\mathrm{o}}(\boldsymbol{\%} \mathbf{p} / \mathbf{v})$ & Agitation $(\mathbf{r p m})$ & $\mathbf{B}(\mathbf{g} / \mathbf{L})$ & $\mathbf{A}_{\mathbf{C}}(\mathbf{U} / \mathbf{m L})$ \\
\hline 1 & 5.5 & 0.75 & 100 & 0.88 & 20.31 \\
2 & 7.5 & 0.75 & 100 & 1.42 & 42.41 \\
3 & 5.5 & 1.25 & 100 & 1.74 & 51.04 \\
$\mathbf{4}$ & $\mathbf{7 . 5}$ & $\mathbf{1 . 2 5}$ & $\mathbf{1 0 0}$ & $\mathbf{1 . 8 6}$ & $\mathbf{6 6 . 8 6}$ \\
5 & 5.5 & 0.75 & 200 & 0.9 & 28.61 \\
6 & 7.5 & 0.75 & 200 & 1.04 & 30.26 \\
7 & 5.5 & 1.25 & 200 & 1.6 & 44.51 \\
8 & 7.5 & 1.25 & 200 & 1.56 & 43.34 \\
9 & 6.5 & 1.0 & 150 & 1.38 & 48.37 \\
10 & 6.5 & 1.0 & 150 & 1.7 & 49.37 \\
11 & 6.5 & 1.0 & 150 & 1.74 & 51.91 \\
12 & 6.5 & 1.0 & 150 & 1.76 & 54.57 \\
\hline
\end{tabular}

${ }^{\mathrm{a}}$ Results refer to $72 \mathrm{~h}$ of fermentation at $30^{\circ} \mathrm{C} \cdot \mathrm{pH}=$ initial medium $\mathrm{pH} ; \mathrm{S}_{\mathrm{o}}=$ Substrate concentration; $\mathrm{X}=$ biomass concentration; $\mathrm{A}_{\mathrm{c}}=$ volumetric collagenolytic activity.

The Pareto bar chart represents the estimated effects of the variables, and their interactions on collagenolytic activity (Figure 1) in decreasing order of magnitude. The length of each bar is proportional to the standardized effect. The vertical line can be used to judge which effects are statistically significant. Bars extending beyond this line correspond to the effects statistically significant at a confidence level of $95 \%$.

It can be seen from Figure 1 that the main significant effects for colagenase production are substrate concentration (2) and initial medium $\mathrm{pH}$ (1). The substrate concentration (2) and $\mathrm{pH}$ (1) showed significant positive effect, suggesting that an increase in these parameter values would improve collagenase production. However, the agitation orbital speed (4) showed significant negative effect. The negative effect means that an increase in this parameter led to a decrease in collagenolytic activity.

In addition, a significant interaction between $\mathrm{pH}$ (1) and orbital agitation speed (3) was observed (Figure 1). The negative interaction effect means that an increase in $\mathrm{pH}$ with a simultaneous increase in orbital agitation speed led to a decrease in collagenolytic activity. 
Another significant interaction between substrate concentration (2) and orbital agitation speed (3) was also observed (Figure 1). The positive interaction effect means that an increase in substrate concentration with a simultaneous increase in orbital agitation speed led to an increase in collagenolytic activity.

It has been reported that effects of nitrogen supplement on protease production differ from organism to organism although complex nitrogen sources are usually used for protease production. In this study, the substrate concentration (gelatin) was the variable that most influenced on collagenase production (Figure 1). Since gelatin is an inexpensive and readily available substrate, it is a possible candidate for the cost-effective production of extracellular protease when used as culture medium ingredient. Lima et al. (2009) performed a study of collagenase production by Candida albicans and observed that the substrate concentration (gelatin) also influenced positively the collagenase production.

Several studies have shown that one important characteristic of most microorganisms is their strong dependence on the extracellular $\mathrm{pH}$ for cell growth and enzyme production (Kumar and Tagaki, 1999). In this study we observed a gradual increase in the collagenase production when the $\mathrm{pH}$ increased from 5.5 to 7.5. Lima et al. (2009) performed a study to determine the best conditions for collagenase production by Candida albicans and observed an increase on collagenase production when the $\mathrm{pH}$ increased from 5.0 to 7.0. Similar results have been obtained by Patel et al. (2005) while studying the effect of gelatin concentration on the production of an extracellular protease produced by Bacillus sp. These authors observed a gradual increase in production with increasing $\mathrm{pH}$, with an optimum at $\mathrm{pH} 9.0$. Chi et al. (2007) also observed that the initial culture medium $\mathrm{pH}$ influenced protease production by the marine yeast A. pullulans, with the highest yields of alkaline protease occurring at an initial $\mathrm{pH}$ of 6.0. Taken together, these results confirm the importance of initial medium $\mathrm{pH}$ on the protease production, although optimum $\mathrm{pH}$ will differ from organism to organism.

As said previously, the results of the first $2^{3}$ full factorial design showed an decrease in the production of collagenase by yeast (13II) when the orbital agitation speed increased from 100 to $200 \mathrm{rpm}$. The orbital agitation speed is important in the microbial synthesis of protease enzymes because this parameter affects the amount of dissolved oxygen. As dissolved oxygen is the rate-limiting factor because of its low solubility in the aqueous solution, it affects the cell grown and yield of products in the aerobic fermentation (Potumarthi et al., 2007). There is no general medium for protease production by different microbial strains. Every microorganism has its own idiosyncratic physicochemical and nutritional requirements for growth and enzyme secretion (Readdy et al., 2008). 
(2) Substrate concentration

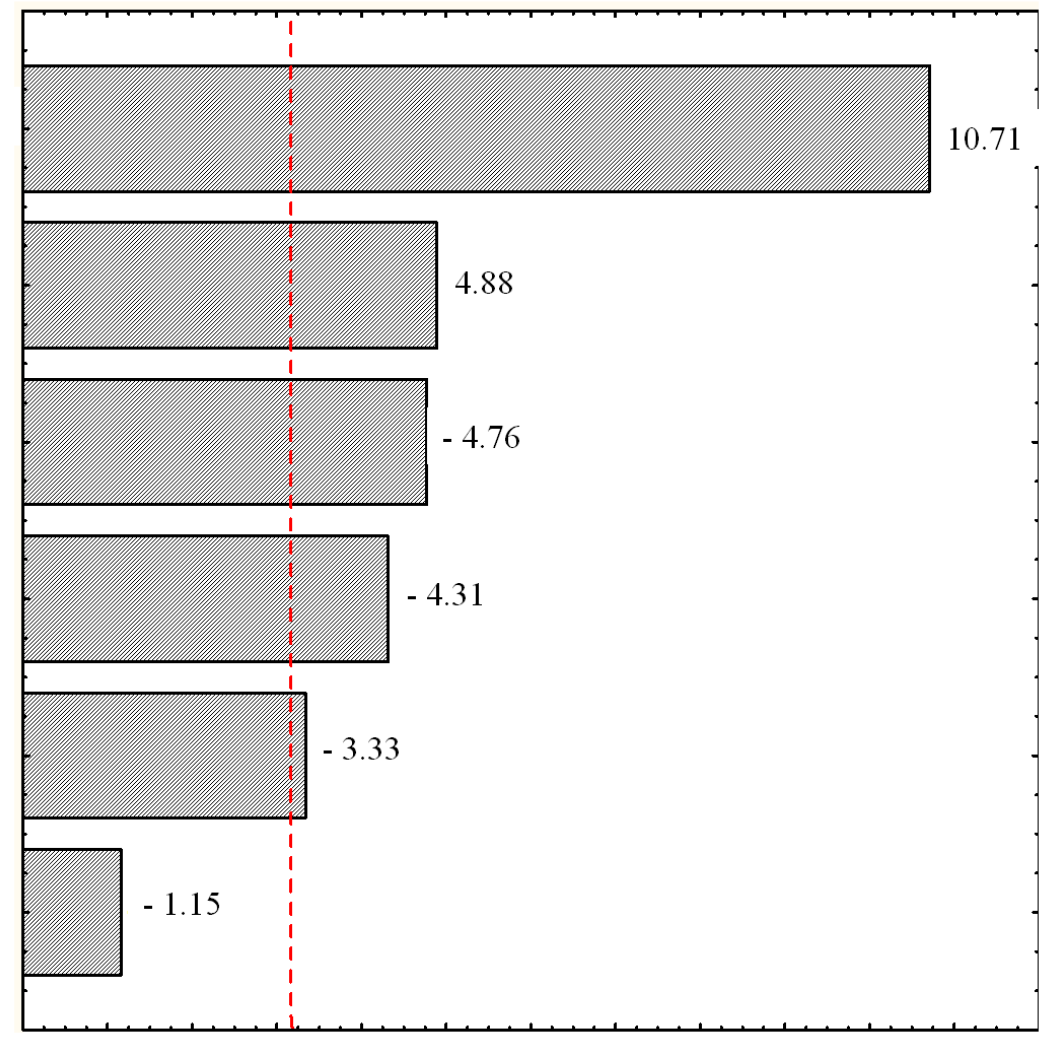

$\mathrm{p}=0.05$

Figure 1 - Pareto chart for the effects of variables $\mathrm{pH}(1)$, substrate concentration (2) and orbital agitation speed (3) on collagenolytic activity from $2^{3}$ full factorial design.

\section{CONCLUSIONS}

The application of factorial experimental design for selection of culture condition for collagenase production by yeast (13II) enables the rapid identification of key factors such as $\mathrm{pH}$, orbital agitation speed and substrate concentration and interactions between them, which together are necessary for the production of collagenase by this microorganism. This study also introduces a new strain of yeast as a potential candidate for the production of a collagenase that could have potential applications in pharmaceutical, leather and food industries.

\section{REFERENCES}

BENITO, M.J.; RODRIGUEZ, M.; NUNEZ, F; ASENSIO, M.A.; BERMUDEZ, M.E. Purification and characterization of an extracellular protease from Penicillium chrysogenum active against meat protein. Appl Environ Microbiol. v. 68, p. 3532-3536, 2002.

CHAVIRA. R.J.; BURNETT. T.J.; HAGEMAN. J.H. Assaying proteinases with azocoll. Anal Biochem. v. 136. p. 4446-4450, 1984. 
CHI, Z.; MA, C.; WANG, P.; LI, H. F. Optimization ofmediumand cultivation conditions for alkaline protease production by the marine yeast Aureobasidium pullulans. Bioresource Technol., v. 98, p. 534-538, 2007.

HADDAR, A.; FAKHFAKH-ZOUARI, N.; HMIDET, N.; FRIKHA, F.; NASRI, M.; KAMOUN, A.S. Low-cost fermentation medium for alkaline protease production by Bacillus mojavensis A21 using hulled grain of wheat and sardinella peptone. J Biosci Bioeng.v. 110, p. 288-294, 2010.

HAMDY, H.S. Extracellular collagenase from Rhizoctonia solani: production. purification and characterization. Ind J Biotechnol. v. 7, p. 333-340, 2008.

JORDAN, G.H. The use of intralesional clostridial collagenase injection therapy for Peyronie's disease: a prospective. singlecenter. non-placebo-controlled study. J Sex Med. v. 5, p. 180-187, 2008.

KANTH, S.V.; VENBA, R.; MADHAN, B.; CHANDRABABU, N.K.; SADULLA, S. Studies on the influence of bacterial collagenase in leather dyeing. Dyes Pigments. v. 76, p. 338-347, 2008.

KIM, M.; HAMILTON, S.E;. GUDDAT, L.W.; OVERALL, C.M. Plant collagenase: unique collagenolytic activity of cysteine proteases from ginger. Biochim Biophys Acta. v. 1770, p.1627-1635, 2007.

KUMAR, C. G.; TAGAKI, H. Microbial alkaline protease: from bioindustrial view point. Biotechnol. Adv., v. 17, p. 561-594, 1999.

LIMA, C. A.; RODRIGUES, P. M. B.; PORTO, T. S.; VIANA, D. A.; LIMA FILHO, J. L.; PORTO, A. L. F.; CARNEIRO DA CUNHA, M. G. Production of a collagenase from Candida albicans URM3622. Biochem. Eng. J., v. 43, p. 315-320, 2009.

NICKERSON. W.J.; MOHAN. R.R. Studies on the nutrition and metabolism of Streptomyces. In: Symposium on Actinomycetales. International Comgress of Microbiology. $6^{\circ}$ Congress. Roma. p. 137-146, 1953.

PATEL, R.; DODIA, M.; SINGH, S.P. Extracellular alkaline protease from a newly isolated haloalkaliphilic Bacillus sp.: production and optimization. Process Biochem. v. 40, p. 3569-3575, 2005.

POTUMARTHI, R.; CH S.; JETTY, A. Alkaline protease production by submerged fermentation in stirred tank using Bacillus licheniformis NCIM-2042: effect of aeration and agitation regimes, Biochem. Eng. J. v. 34, p. 185-192, 2007.

REDDY, L.V.A.; WEE, Y.J.; YUN, J.S.; RYU, H.W. Optimization of alkaline protease production by batch culture of Bacillus sp. RKY3 through Plackett-Burman and response surface methodological approaches. Bioresource Technol. v. 99, p. 22422249, 2008. 
SEGEV, A.; NILI, N.; QIANG, B.; CHARRON, T.; BUTANY, J.; STRAUSS, B.H. Humangrade purified collagenase for the treatment of experimental arterial chronic total occlusion. Cardiovasc Revasc Med. v. 6, p. 65-69, 2005.

SMITH. P.K.; KROHN. R.I.; HERMANSON. G.T.; MALLIA. A.K.; GARDENER. F.H.; PREVENANO. M.D..; FUJIMOTO. C.K.; GOEKE. N.M.; OLSON. B.J.; KLENK. D.C. Measurement of protein using bicinchoninic acid. Anal Biochem.. v. 150, p. 76-85, 1985.

SUHOSYROVA, E.A.; NIKITINA, Z.K.; YAKOVLEVA, M.B.; VESHCHIKOVA, E.V.; BYKOV, V.A. Characterstics of collagenolytic enzymes secreted by Deuteromycete Fungi Aspergillus Flavus. Immunol Microbiol. v. 125, p. 447-451, 2003.

TAMAI, E.; MIYATA, S.; TANAKA, H.; NARIYA, H.; SUZUKI, M.; MATSUSHITA, O.; HATANO, N.; OKABE, A. High-level expression of his-tagged clostridial collagenase in Clostridium perfringens. Appl Microbiol Biotechnol. v. 80, p. 627-635, 2008.

TANDER, B.; BICAKCI, U.; KILICOGLU-AYDIN, B.; ARITURK, E.; RIZALAR, R.; BERNAY, F. Antiadhesive effects of mitomycin C and streptopeptidase A in rats with intraperitoneal adhesions. Pediatr Surg Int. v. 23, p. 785-788, 2007.

WU, Q.; LI, C.; LI, C.; CHEN, H.; SHULIANG, L. Purification and characterization of a novel collagenase from Bacillus pumilus Col-J. Appl Biochem Biotechnol. v. 160, p. 129-139, 2010. 